\title{
Ceramic/metal biocidal nanocomposites for bone-related applications
}

\author{
Miriam Miranda $^{\mathrm{a}^{*}}$, Adolfo Fernández ${ }^{\mathrm{b}}$, Sonia Lopez-Esteban ${ }^{\mathrm{a}}$, Francisco Malpartida ${ }^{\mathrm{c}}$, \\ José S. Moya ${ }^{\mathrm{d}}$, Ramón Torrecillas ${ }^{\mathrm{a}}$ \\ ${ }^{a}$ Centro de Investigación en Nanomateriales y Nanotecnología (CINN-CSIC-UO-PA), Llanera, Spain. \\ ${ }^{b}$ ITMA Materials Technology, Llanera, Spain. \\ ${ }^{c}$ Centro Nacional de Biotecnología (CNB-CSIC), 28049, Cantoblanco, Spain. \\ ${ }^{d}$ Instituto de Ciencia de Materiales de Madrid (ICMM), Consejo Superior de Investigaciones Científicas \\ (CSIC), Cantoblanco, Spain. \\ *Corresponding autor. CINN-CSIC. Parque Tecnológico de Asturias, 33428, Llanera, Spain. Tel.: +34- \\ 985.98.00.58. Fax: +34-985.26.55.74. Email: m.miranda@cinn.es
}

\begin{abstract}
Hydroxyapatite/silver nanocomposites have been designed and synthesized as an engineering material for biomedical applications. The hydroxyapatite matrix was synthesized by a sol-gel method and, subsequently, the Ag nanoparticles were deposited by heterogeneous precipitation followed by two different reduction routes: thermal or chemical. Both sets were studied and compared and, in all cases, the metal nanoparticles appear perfectly isolated and attached to the surface of the hydroxyapatite. The average metal particle size is below $10 \mathrm{~nm}$, allowing an important contact surface between silver and the microorganisms. The antimicrobial behavior against common bacteria showed a high effectiveness, well above the commercial level, as well as against yeast, in the case of the chemically reduced sample. Due to the nanocomposite microstructure, only a negligible portion of metal was released to the lixiviated liquid after the biocide tests, minimizing the risk of toxicity. These nanocomposites offer a solution to the infections on the surface of implants, one of the main problems in reaching a suitable level of osseointegration.
\end{abstract}

Keywords: hydroxyapatite, silver, antibacterial, nanoparticle, composite. 


\section{Introduction}

Nowadays, much effort is being devoted in the field of nanomaterials to the fabrication of a new generation of reliable and longer-lasting implants for joint replacement [1]. Unfortunately, the appearance of infection in the tissues surrounding an implant is a factor that often decreases the success and life-span of the artificial device. The prevention of a biofilm formation is crucial in order to avoid complications due to bacterial infections after the implant positioning [2], for example, ostomyelitis and prosthetic joint infections are some of the pathogenesis that can take place in the case of orthopaedic infections in the presence of biofilm $[3,4]$.

A remarkable new approach to try to solve this problem has focused on ceramicmatrix composites with metal particles embedded as a second phase, which have been proved to present mechanical and functional features which are useful for a wide range of applications [5-10]. It deals specifically with a hydroxyapatite matrix [HA, $\left.\mathrm{Ca}_{10}\left(\mathrm{PO}_{4}\right)_{6}(\mathrm{OH})_{2}\right]$ with embebbed silver nanoparticles (HA/Ag) [11, 12]. This nanocomposite has been proposed for several reasons. Firstly, hydroxyapatite works out as the ceramic matrix, as it is the main inorganic phase in bones and is osseoinductor, which makes it a candidate material for biomedical applications [13] (implants [14-16], drug carriers [17-19], bone tissue engineering scaffolds [20-22], etc). Secondly, silver has been the metal selected, as it has been for a long time a well known antibacterial, exhibiting activity against a broad spectrum of different bacteria, and even some bacterial strains with resistance against antibiotics $[23,24]$. The preliminary studies of the behavior of these nanocomposites against some specific microorganisms has shown a promising biocidal effect $[11,12]$ and the need to be studied in depth from multiple 
points of view: from the synthesis and preparation of the material up to the study of the interaction material/microorganism.

In this work, two different routes to obtain HA/Ag nanocomposites are proposed. The physico-chemical properties of the resulting samples are compared and the antimicrobial benefits of the composites are evaluated against bacteria and yeast. Furthermore, the interaction of the nanoparticles with the microorganisms is studied in detail.

\section{Materials and methods}

\subsection{Samples preparation}

The HA nanopowder was prepared in situ in the laboratory following the sol-gel route resumed in the flow chart in Fig. 1A and previously described elsewhere [11].

Regarding the preparation of the HA-Ag composite nanopowder, two different methods were followed depending on the reduction treatment. In the first procedure, the precursor was thermally reduced (samples labeled as $H A / n A g-T h$ ), while in the second case a chemical reduction was used (HA/nAg-Ch samples). In both cases, the first step was the preparation of a HA aqueous suspension ( 9 wt. $\%$ of solids loading); a dispersant (Dolapix CE-64) was added to improve the suspension stability at $\mathrm{pH}=7$. At this $\mathrm{pH}$ there was a compromise, as on one hand no precipitation of the silver precursor took place and on the other hand, the solubility of calcium from the HA was extremely low, as shown in Fig. 2.

The suspension was ball milled for 24 hours and, subsequently, the silver precursor suspension was dropped to reach a concentration of silver of $1 \mathrm{wt} . \%$ in the 
final product. In the case of $\mathrm{HA} / \mathrm{nAg}$-Th, as shown in Fig. 1B, the $\mathrm{pH}$ was adjusted to 9 by dropping a $\mathrm{NaOH}$ aqueous solution $1 \mathrm{M}$ to precipitate $\mathrm{Ag}^{+}$as $\mathrm{Ag}_{2} \mathrm{O}$, according to the potential-pH diagram in aqueous solution for silver [25]. The material is centrifuged at $3500 \mathrm{rpm}$ and dried. The reduction takes place at $350^{\circ} \mathrm{C}$ for 2 hours in a controlled atmosphere of $\mathrm{H}_{2} / \mathrm{Ar} 10 / 90$.

In the case of the HA/nAg-Ch sample, there was a chemical reduction with sodium borohydride $\left(\mathrm{NaBH}_{4}\right.$, Sigma-Aldrich) as reductor agent, as described elsewhere [12]. It was added quickly into the stirred suspension with the HA and silver precursor to promote the precipitation of $\mathrm{Ag}^{0}$ according to the next reactions:

$$
\begin{aligned}
& 8\left(\mathrm{Ag}^{+}+1 \mathrm{e}^{-} \leftrightarrow \mathrm{Ag}^{0}\right) \\
& \frac{\mathrm{BH}_{4}^{-}+3 \mathrm{H}_{2} \mathrm{O} \leftrightarrow \mathrm{B}(\mathrm{OH})_{3}+7 \mathrm{H}^{+}+8 \mathrm{e}^{-}}{8 \mathrm{Ag}^{+}+\mathrm{BH}_{4}^{-}+3 \mathrm{H}_{2} \mathrm{O} \leftrightarrow 8 \mathrm{Ag}^{0}+\mathrm{B}(\mathrm{OH})_{3}+7 \mathrm{H}^{+}}
\end{aligned}
$$

Afterwards, as in the case of $\mathrm{HA} / \mathrm{nAg}$-Th, the powder was centrifuged and dried. Different dry treatments were compared in the case of $\mathrm{HA} / \mathrm{nAg}-\mathrm{Ch}$ to optimize the nanoparticle size distribution; three temperatures $\left(60,150\right.$ and $250^{\circ} \mathrm{C}$, respectively) and a lyophilization treatment were compared. All the steps in both procedures to add the silver were carried out in a dark room to avoid the spontaneous reduction of silver cations due to the presence of light.

\subsection{Characterization techniques}

A thermogravimetric analysis (TGA) was carried out in TGA using TAInstruments Model SDT 2960). The particle size distribution was determined in a Coulter LS 13320 particle size analyzer equipped with a laser source $(\lambda=750 \mathrm{~nm}) . \mathrm{X}$ - 
ray powder diffraction (XRD) patterns were registered using a Bruker D8 Advance diffractometer with a $\mathrm{Cu} \mathrm{K}_{\alpha}$ radiation source at a scan speed of $0.5 \% \mathrm{~min}$. The transmission electron microscopy (TEM) images were obtained with a Field Emission TEM FEI Tecnai F20. UV-vis spectroscopy was performed using a Cary 4000 uv-vis spectrophotometer.

The biocide activity was measured against three different microorganisms: Escherichia coli JM 110 (Gram-negative bacteria), Micrococcus luteus (Gram-positive bacteria) and Issatchenkia orientalis (yeast). The media used were Luria Bertani (LB) for Escherichia coli JM 110 and Micrococcus luteus, and for Issatchenkia orientalis it was yeast extract dextrose (YEPD). $10 \mu \mathrm{L}$ of a saturated suspension according to the microorganism to be studied were added to $1 \mathrm{~mL}$ of the corresponding medium. Subsequently, an aqueous suspension of each $\mathrm{HA} / \mathrm{nAg}$ sample was prepared with a concentration of $20 \mathrm{wt} . \%$, and $150 \mu \mathrm{L}$ were added to the medium with the microorganisms. For each test a silver free media was used as a control (the sample suspension was replaced by water). The inoculums were incubated at $30^{\circ} \mathrm{C}$ with horizontal shake for $48 \mathrm{~h}$. The number of colonies was counted every $24 \mathrm{~h}$.

\section{Results and discussion}

\subsection{HA nanopowders}

The first goal was to determine the temperature of crystallization of HA from the thermogravimetric analysis of the dried hydroxyapatite gel (Fig. 3A). The test was carried out in air, at a heating rate of $5^{\circ} \mathrm{C} / \mathrm{min}$ in the range $25-1000^{\circ} \mathrm{C}$. An endothermal peak was observed around $550^{\circ} \mathrm{C}$ and it was initially associated with the crystallization 
of HA. In order to test this hypothesis, several calcination temperatures were tested to study the resulting crystallinity: $300^{\circ} \mathrm{C}, 475^{\circ} \mathrm{C}$ and $550^{\circ} \mathrm{C}$.

The resulting phases were analyzed by XRD, showing a clear difference in crystallinity between all the samples (Fig. 3B). Thus, the powder resulting at $300^{\circ} \mathrm{C}$ corresponded to totally amorphous $\mathrm{HA}$; the powder calcined at $475^{\circ} \mathrm{C}$ was partially amorphous, showing poorly defined peaks; finally, the powder resulting at $550^{\circ} \mathrm{C}$ corresponded to pure, stoichiometric and crystalline HA. For this reason, the temperature chosen for the heat treatment was $550^{\circ} \mathrm{C}$.

The granulometric analysis (Fig. 4A) shows a narrow particle size distribution with an average particle size around $125 \mathrm{~nm}$, in agreement with TEM observations (Fig. 4B). The parameter $d_{90}$ indicates that $90 \%$ of the HA particles present a size below 155 nm. It is also possible to differentiate the crystallographic planes (Fig. 4B). In summary, the hydroxyapatite obtained by the followed sol-gel route was pure, stoichiometric and crystalline, with an average size $\mathrm{d}_{90}$ below $155 \mathrm{~nm}$.

\subsection{HA/nAg nanocomposites}

In order to verify whether the final size distribution of the silver nanoparticles was affected or not by the method of drying the powders, different dry temperatures were tested in the oven and the results were also compared with those obtained by lyophilization (Table 1). This study was carried out with the sample chemically reduced (HA/nAg-Ch) because it will no suffer any further heat treatment and, therefore, is more sensitive to the dry process. As shown in Table 1, the size obtained by lyophilization is lower than any of those obtained by a thermal treatment. Therefore, lyophilization hinders the nanoparticle agglomeration better than the thermal treatments. According to 
these results, both sets of samples (HA/nAg-Th, HA/nAg-Ch) were dried by lyophilization, in order to keep the metal particle size as small as possible. Thus, the metallic surface exposed to the microorganisms will increase, which is expected to enhance the bactericidal activity of the composite.

In the XRD analysis of the samples, no other phases other than HA and Ag were detected (Fig. 5A). It is important to emphasize that neither destabilization nor dissolution of hydroxyapatite took place during the synthesis of Ag nanoparticles.

One tool commonly used to characterize nanoparticles is surface plasmon resonance. In the particular case of silver nanoparticles, the main peak is normally presented at around $420 \mathrm{~nm}$. Depending on the surroundings of the nanoparticles and their size and shape distribution, the position and shape of the band can vary [26, 27]. This can be seen in Fig. 5B, which shows the UV-VIS spectrum for HA/nAg-Th and $\mathrm{HA} / \mathrm{nAg}$-Ch, with the light absorption maxima corresponding to the surface plasmon resonance located at $426 \mathrm{~nm}$. This single peak, clearly defined in both cases, is representative of globular particles, with a narrow distribution of sizes and homogeneity in particle shape. The position and shape of the surface plasmon absorption band is similar to those found by other authors [28-30]. In the case of several geometries or bimodal size distribution, more peaks appear at different wavelengths. The different intensity between the peaks of $\mathrm{HA} / \mathrm{nAg}$-Th (thermally reduced) and $\mathrm{HA} / \mathrm{nAg}$-Ch (chemically reduced) may be related to the number of particles (which is higher in the case of $\mathrm{HA} / \mathrm{nAg}-\mathrm{Ch}$ ), and the possible presence of silver deposits in HA/nAg-Th.

Fig. 6A and Fig. 6B show some TEM images for HA/nAg-Th and HA/nAg-Ch, respectively. In both cases, in the samples obtained by both reduction procedures, the 
silver nanoparticles appear perfectly isolated and attached to the surface of the hydroxyapatite particles. The HA matrix acts as an effective scaffold where the nanoparticles are dispersed, avoiding their agglomeration. This is an important feature because a larger contact surface between silver and the microorganisms is expected to increase the bactericidal activity of the composite. Therefore, the small size of the silver nanoparticles ensures that a significantly large surface area is in contact with the microorganisms. It is also possible to observe the globular shape of the particles, in agreement with the information obtained from the surface plasmon.

It can be roughly inferred from numerous TEM micrographs that the average particle size of the silver nanoparticles is below $10 \mathrm{~nm}$. A size distribution was carried out to study this issue and the information is shown Fig. 7. The parameter $d_{90}$ is 15.96 nm and $10.01 \mathrm{~nm}$ for $\mathrm{HA} / \mathrm{nAg}-\mathrm{Th}$ and $\mathrm{HA} / \mathrm{nAg}-\mathrm{Ch}$, respectively.

The average size of the Ag nanoparticles in the case of HA/nAg-Ch (chemically reduced samples) was $7.02 \mathrm{~nm}$, slightly below that corresponding to the $\mathrm{HA} / \mathrm{nAg}$-Th sample (thermally reduced samples), $8.85 \mathrm{~nm}$. Therefore, the bacterial activity of $\mathrm{HA} / \mathrm{nAg}-\mathrm{Ch}$ might have been higher than that of $\mathrm{HA} / \mathrm{nAg}-\mathrm{Th}$, due to the smaller silver nanoparticles. In order to test this hypothesis, it was necessary to test the bacterial activity of both types of samples in the laboratory.

The logarithmic reduction rate $(\log \eta)$ was used to evaluate the bacterial activity of the samples. During the test, the viable microorganisms were counted after 24 and 48 hours. Fig. 8 shows the results for both samples and compares them with a commercial broad-spectrum antibacterial material [31]. Pure HA was tested as a control, showing no activity. Regarding the activity against bacteria, there was a high activity in both 
samples, well above the commercial level (marked in Fig. 8 with discontinuous line), and there was no difference between the activity of $\mathrm{HA} / \mathrm{nAg}$-Th and $\mathrm{HA} / \mathrm{nAg}-\mathrm{Ch}$. However, in the case of yeast (I. Orientalis), only HA/nAg-Ch exceeded the disinfection limit of a commercial antimicrobial product, showing a more effective behavior. The lower effectiveness of the samples against the yeast may be related to the different external membrane structure of the cells [32].

Other composite materials with silver nanoparticles have been found in the literature and show effectiveness against bacteria while are inactive against yeast [33]. As shown in Fig. 8, the $\mathrm{HA} / \mathrm{nAg}$ composite is effective against both kinds of microorganisms.

Fig. 9 shows a sequence in chronological order of four TEM micrographs during the treatment of E. coli with $\mathrm{HA} / \mathrm{nAg}$-Ch. The $\mathrm{Ag}$ nanoparticles in contact with the membrane caused permeability and, subsequently, cell death [34]. At the beginning of the process (Fig. 9A), the particles are attached to the bacteria surface. The next step is the rupture of the cellular membrane (Fig. 9B), that enabled the penetration of the particles inside the bacteria and it was also possible to observe the destruction of the microorganism (Fig. 9C). Fig. 9D shows the appearance of a dead bacterium with the membrane completely ruptured. Therefore, this sequence corroborates that the membrane is one of the attack points of the silver nanoparticles.

Moreover, silver cations, $\mathrm{Ag}^{+}$, are more aggressive against cell tissues than metallic silver, $\mathrm{Ag}^{0}$. For this reason, in order to determine whether silver was in the liquid in the form of either cationic silver or metallic silver, the liquid was analyzed by UV-VIS spectroscopy. In Fig. 10 the curves corresponding to the surface plasmon 
resonance are shown and it is possible to assert that the silver present is in metallic form and, therefore, the possible risks are minimized.

\section{Conclusions}

This work presents the synthesis and antimicrobial study of a set of hydroxyapatite/silver nanocomposites. Firstly, a method for the synthesis of the HA nanopowder was presented. Subsequently, two different methods for the addition of a second phase consisting in silver nanoparticles were tested: the first one followed a thermal reduction and the second one a chemical reduction. In both cases, the silver nanoparticles were perfectly isolated and attached to the surface of the hydroxyapatite. Regarding the activity against bacteria, there was a high activity in both samples; however, in the case of yeast, only the chemically reduced sample (HA/nAg-Ch) exceeded the disinfection limit of a commercial antimicrobial product. The combination of the bioactivity of the ceramic matrix with the biocide activity of the silver nanoparticles makes this material an excellent candidate for implants, bone filling and reconstructive surgery applications. In conclusion, this work demonstrates the effectiveness of the material as biocide and the low risk in its use in bone-related applications.

\section{Acknowledgements}

This work was supported by the Spanish Ministry of Science and Innovation (MICINN) under the project MAT2009-14542-C02 and by the Spanish National Research Council (CSIC) under the PIE Project 200860I118. Miriam Miranda has been supported by the Government of the Principality of Asturias under the Severo Ochoa Program. 
[1] Torrecillas RR, Moya JS, Diaz LA, Bartolome JF, Fernandez A and Lopez-Esteban S. Nanotechnology in joint replacement. Wiley Interdisciplinary Reviews: Nanomedicine. 2007;1:540-52.

[2] Chen W, Liu Y, Courtney HS, Bettenga M, Agrawal CM, Bumgardner JD and Ong JL. In vitro anti-bacterial and biological properties of magnetron co-sputtered silvercontaining hydroxyapatite coating. Biomaterials. 2006;27:5512-7.

[3] Socransky SS and Haffajee AD. Dental biofilms: difficult therapeutic targets. Periodontology. 2002;28:12-55.

[4] Patel R. Biofilms and Antimicrobial Resistance. Clinical Orthopaedics and Related Research. 2005;437:41-7.

[5] Moya JS, Lopez-Esteban S and Pecharroman C. The challenge of ceramic/metal (micro- and nano-) composites. Prog. Mater. Sci. 2007;52:1017-90.

[6] Fahrenholtz WG, Ellerby DT and Loehman RE. $\mathrm{Al}_{2} \mathrm{O}_{3}-\mathrm{Ni}$ Composites with High Strength and Fracture Toughness. Journal of the American Ceramic Society. 2000;83: $1279-80$.

[7] Williamson RL, Bruck HA, Wang XL, Watkins TR, Feng YZ and Clarke DR. Residual Strains in an A12O3-Ni Joint Bonded with a Composite. Interlayer Journal of the American Ceramic Society. 1998;81:1541-9.

[8] Diaz M, Bartolomé JF, Requena J and Moya JS. Wet processing of mullite/molybdenum composites. Journal of the European Ceramic Society. 2000;20:1907-14.

[9] Wildan M, Edrees HJ and Hendry A. Ceramic matrix composites of zirconia reinforced with metal particles. Materials Chemistry and Physics. 2002;75:276-83. 
[10] Xiang X, Zu XT, Zhu S and Wang LM. Optical properties of metallic nanoparticles in Ni-ion-implanted $\alpha-\mathrm{Al}_{2} \mathrm{O}_{3}$ single crystals. Applied Physics Letters. 2004;84:52-4.

[11] Díaz M, Barba F, Miranda M, Guitián F, Torrecillas R and Moya JS. Synthesis and Antimicrobial Activity of a Silver-Hydroxyapatite Nanocomposite. Journal of Nanomaterials. 2009:498505.

[12] Miranda M, Fernández A, Díaz M, Esteban-Tejeda L, López-Esteban S, Malpartida F, Torrecillas R and Moya JS. Silver-hydroxyapatite nanocomposites as bactericidal and fungicidal materials. Int. J. Mat. Res. 2010;101:1.

[13] Legerps RZ, Traity OR, Legeros JP, Edward K and Shirra WP. Apatite Crystallites: Effects of Carbonate on Morphology. Science. 1967;155:1409-11.

[14] Noro T and Ito K. Biomechanical behavior of hydroxyapatite as bone substitute material in a loaded implant model. On the surface strain measurement and the maximum compression strength determination of material crash. Bio-Medical Materials and Engineering. 1999;9:319-24.

[15] Ylinen P, Raekallio M, Taurio R, Vihtonen R, Vainionpää S, Partio EK, Törmälä P and Rokkanen P. Coralline hydroxyapatite reinforced with polylactide fibres in lumbar interbody implantation. Journal of Materials Science: Materials in Medicine. $2005 ; 16: 325-31$.

[16] Hao L, Savalani MM, Zhang Y, Tanner KE, Heath RJ and Harris RA. Characterization of Selective Laser-Sintered Hydroxyapatite-Based Biocomposite Structures for Bone Replacement. Proceedings: Mathematical, Physical and Engineering Sciences. 2007;463:1857-69.

[17] Palazzo B, Sidoti MC, Roveri N, Tampieri A, Sandri M, Bertolazzi L, Galbusera F, Dubini G, Vena P and Contro R. Controlled drug delivery from porous hydroxyapatite 
grafts: An experimental and theoretical approach. Materials Science and Engineering: C. 2005;25:207-13.

[18] Krisanapiboon A, Buranapanitkit B and Oungbho B. Biocompatability of hydroxyapatite composite as a local drug delivery system. Journal of Orthopaedic Surgery. 2006;14:315-8.

[19] Ravelingien M, Smets N, Mullens S, Luyten J, Vervaet C and Remon JP. Local drug delivery from hydroxyapatite ceramic fibres. 4th European Conference of the International Federation for Medical and Biological Engineering, IFMBE Proceedings. 2009;22:2269-72.

[20] Venugopal J, Prabhakaran MP, Zhang Y, Low S, Choon AT and Ramakrishna S. Biomimetic hydroxyapatite-containing composite nanofibrous substrates for bone tissue engineering. Philosophical Transactions of the Royal Society A. 2010;368:2065-81.

[21] Qian P, Jiang F, Huang P, Zhou S, Weng J, Bao C, Zhang C and Yu H. A novel porous bioceramics scaffold by accumulating hydroxyapatite spherules for large bone tissue engineering in vivo. I. Preparation and characterization of scaffold. Journal of Biomedical Materials Research Part A. 2010;93A:920-9.

[22] Bonfield W. Designing Porous Scaffolds for Tissue Engineering. Philosophical Transactions: Mathematical, Physical and Engineering Sciences. 2006;364:227-32.

[23] Liu JK, Yang XH and Tian XG. Preparation of silver/hydroxyapatite nanocomposite spheres. Powder Technology. 2008;184:21-4.

[24] Percival SL, Bowler PG and Russell D. Bacterial resistance to silver in wound care. Journal of Hospital Infection. 2005;60:1-7. 
[25] Pourbaix M. Atlas of electrochemical equilibria in aqueous solutions. Houston (Texas). National Association of corrosion Engineers. 1974.

[26] Thomas S, Nair SK, Jamal EMA, Al-Harthi SH, Varma MR and Anantharaman MR. Size-dependent surface plasmon resonance in silver silica nanocomposites. Nanotechnology. 2008;19:075710.

[27] Esteban-Cubillo A, Diaz C, Fernandez A, Diaz LA, Pecharroman C, TorrecillasR and MoyaJS. Silver nanoparticles supported on $\alpha-, \eta$ - and $\delta$-alumina. J. Eur. Ceram. Soc. $2006 ; 26: 1-7$.

[28] Arumugan SK, Sastry TP, Sreedhar B and Mandal AB. One step synthesis of silver nanorods by autoreduction of aqueous silver ions with hydroxyapatite: An inorganicinorganic hybrid nanocomposite. J. Biomed. Mater. Res. Part A. 2007;80A:391-8.

[29] Pal S, Tak YK and Song JM. Does the Antibacterial Activity of Silver Nanoparticles Depend on the Shape of the Nanoparticle? A Study of the Gram-Negative Bacterium Escherichia coli. Applied and Environmental Microbiology. 2007;73:171220.

[30] Panáček A, Kvítek L, Prucek R, Kolář M, Večeřová R, Pizúrová N, Sharma VK, Nevěčná T and Zbořil R. Silver colloid nanoparticles: synthesis, characterization, and their antibacterial activity. J. Phys. Chem. B. 2006;110:16248-53.

[31] Esteban-Cubillo A, Pecharromán C, Aguilar E, Santarén J and Moya JS. Antibacterial activity of copper monodispersed nanoparticles into sepiolite. J. Mater. Sci. 2006;41:5208-12.

[32] Kim JS, Kuk E, Yu KN, Kim JH, Park SJ, Lee HJ, Kim SH, Park YK, Park YH, Hwang CY, Kim YK, Lee YS, Jeong DH and Cho MH. Antimicrobial effects of silver nanoparticles. Nanomedicine: Nanotechnology, Biology and Medicine. 2007;3:95-101. 
[33] Cabal B, Torrecillas R, Malpartida F and Moya JS. Heterogeneous precipitation of silver nanoparticles on kaolinite plates. Nanotechnology. 2010:475705.

[34] Sondi I and Salopek-Sondi B. Silver nanoparticles as antimicrobial agent: a case study on E. coli as a model for Gram-negative bacteria. J. Colloid. Interface Sci. 2004;275:177-82.

[35] Ayala-Núñez N, Lara Villegas H, del Carmen Ixtepan Turrent L and Rodríguez Padilla C. Silver Nanoparticles Toxicity and Bactericidal Effect Against MethicillinResistant Staphylococcus aureus: Nanoscale Does Matter. NanoBioTechnology. 2009;5:2-9. 


\section{Figure Captations}

Fig. 1 A. Synthesis of pure hydroxyapatite nanopowder. B. Synthesis of HA/nAg composite nanopowder

Fig. 2 HA solubility curve for different $\mathrm{pH}$ values

Fig. 3 A. TG/DTA curves to determine the conditions of the heat treatment to obtain HA powder. B. X-ray diffractograms for samples calcined at $300^{\circ} \mathrm{C}, 475^{\circ} \mathrm{C}$ and $550^{\circ} \mathrm{C}$, leading to amorphous HA, partially amorphous HA and crystalline HA, respectively

Fig. 4 A. Particle size distribution of the HA powder. B. TEM micrograph showing the size and morphology of the HA nanoparticles synthesized and detail of the crystallographic planes

Fig. 5 A. XRD graphics for both samples of HA with nAg. B. UV-vis spectrum of the $\mathrm{HA} / \mathrm{nAg}$ samples showing the surface plasmon band of silver nanoparticles in both samples

Fig. 6 A. TEM micrographs of the thermally reduced sample, HA/nAg-Th. B. TEM micrographs of the chemically reduced sample, $\mathrm{HA} / \mathrm{nAg}-\mathrm{Ch}$, and detail of a $\mathrm{Ag}$ nanoparticle attached to the surface of a HA particle

Fig. 7 Particle size distribution of silver nanoparticles obtained by both reduction methods

Fig. 8 Logarithm reduction used to characterize the effectiveness of the biocide agent for bacteria E. coli, M. luteus and yeast I. orientalis studied at 24 and 48 hours

Fig. 9A-D TEM micrographs showing the sequence of stages when $E$. coli is exposed to $\mathrm{HA} / \mathrm{nAg}$ powder

Fig. 10 Curves corresponding to the surface plasmon resonance of silver in the lixiviated liquid of $\mathrm{HA} / \mathrm{nAg}-\mathrm{Ch}$ 
A)
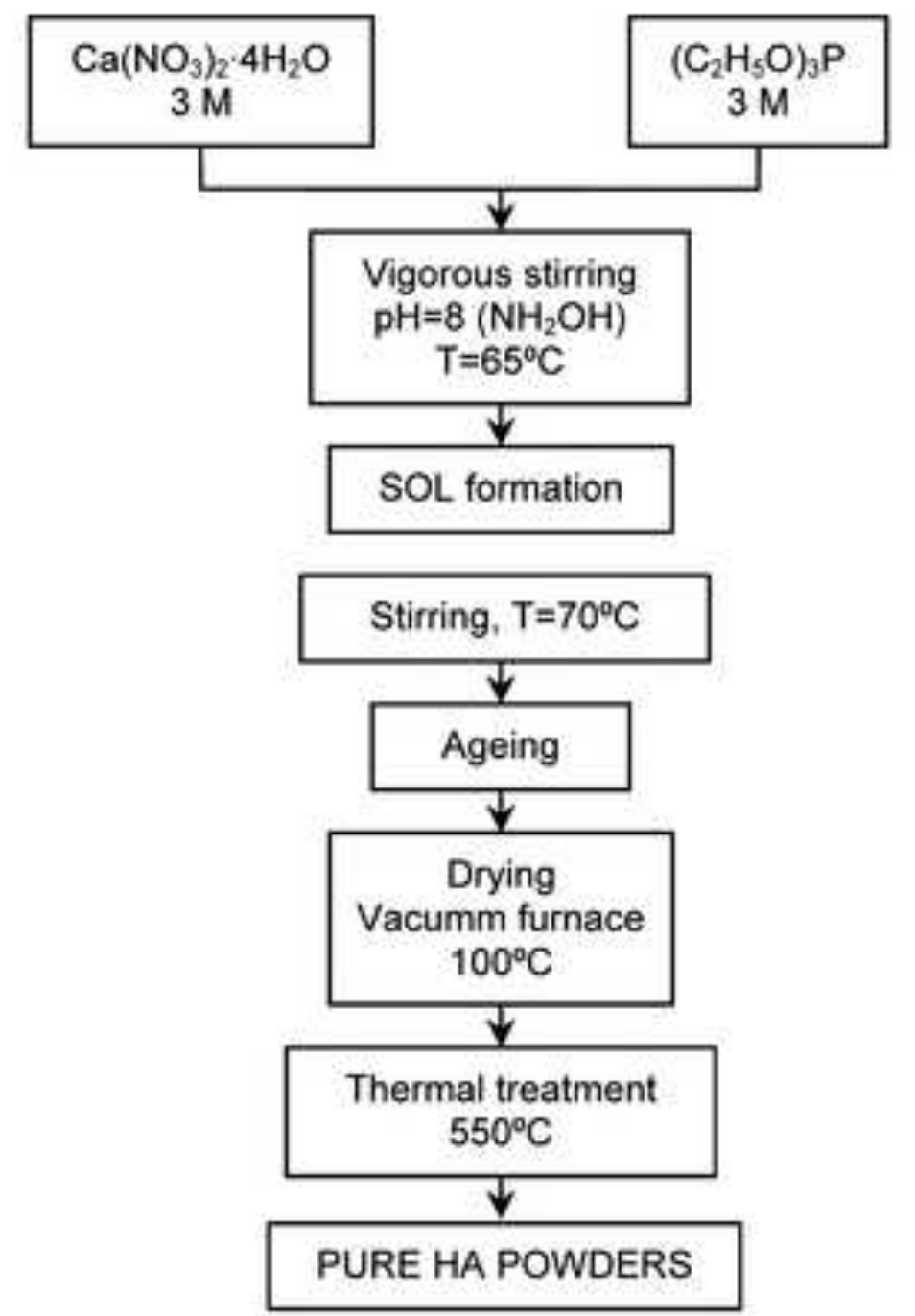

B)

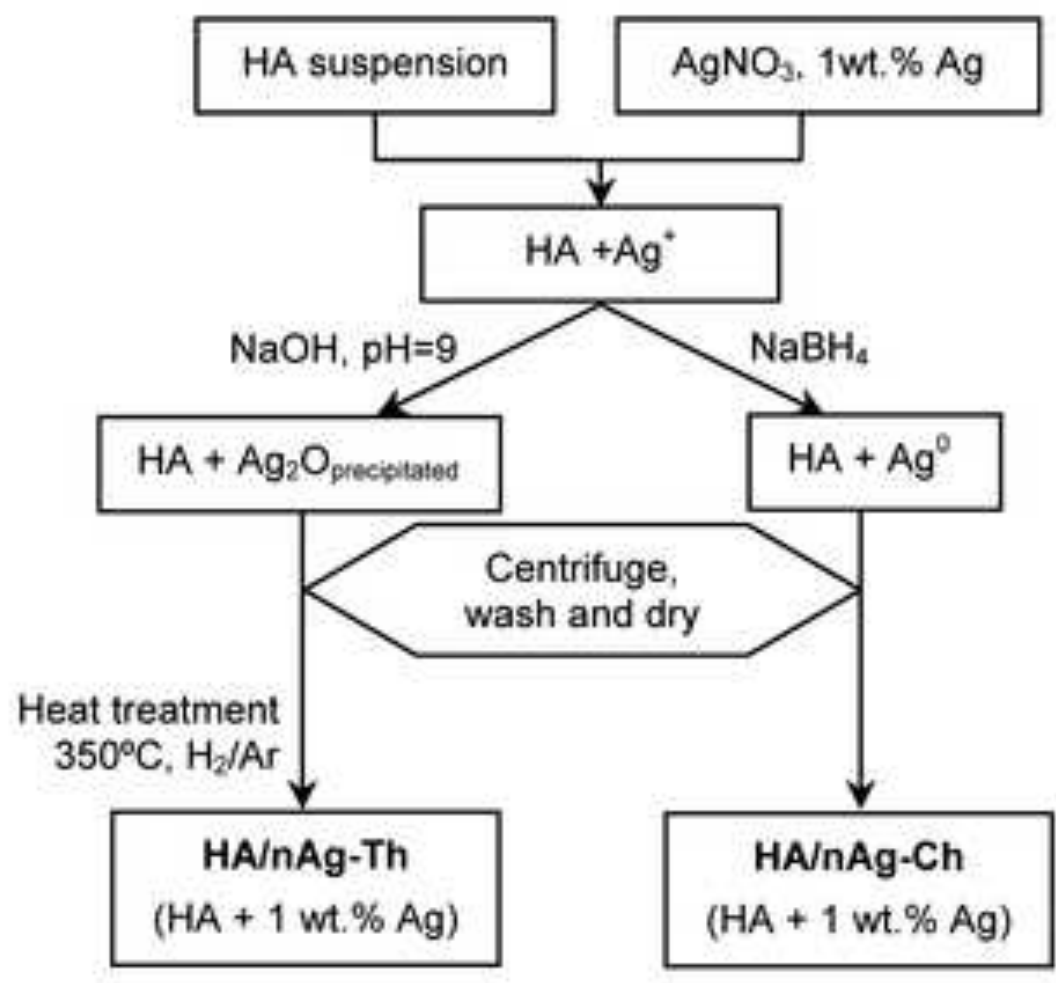




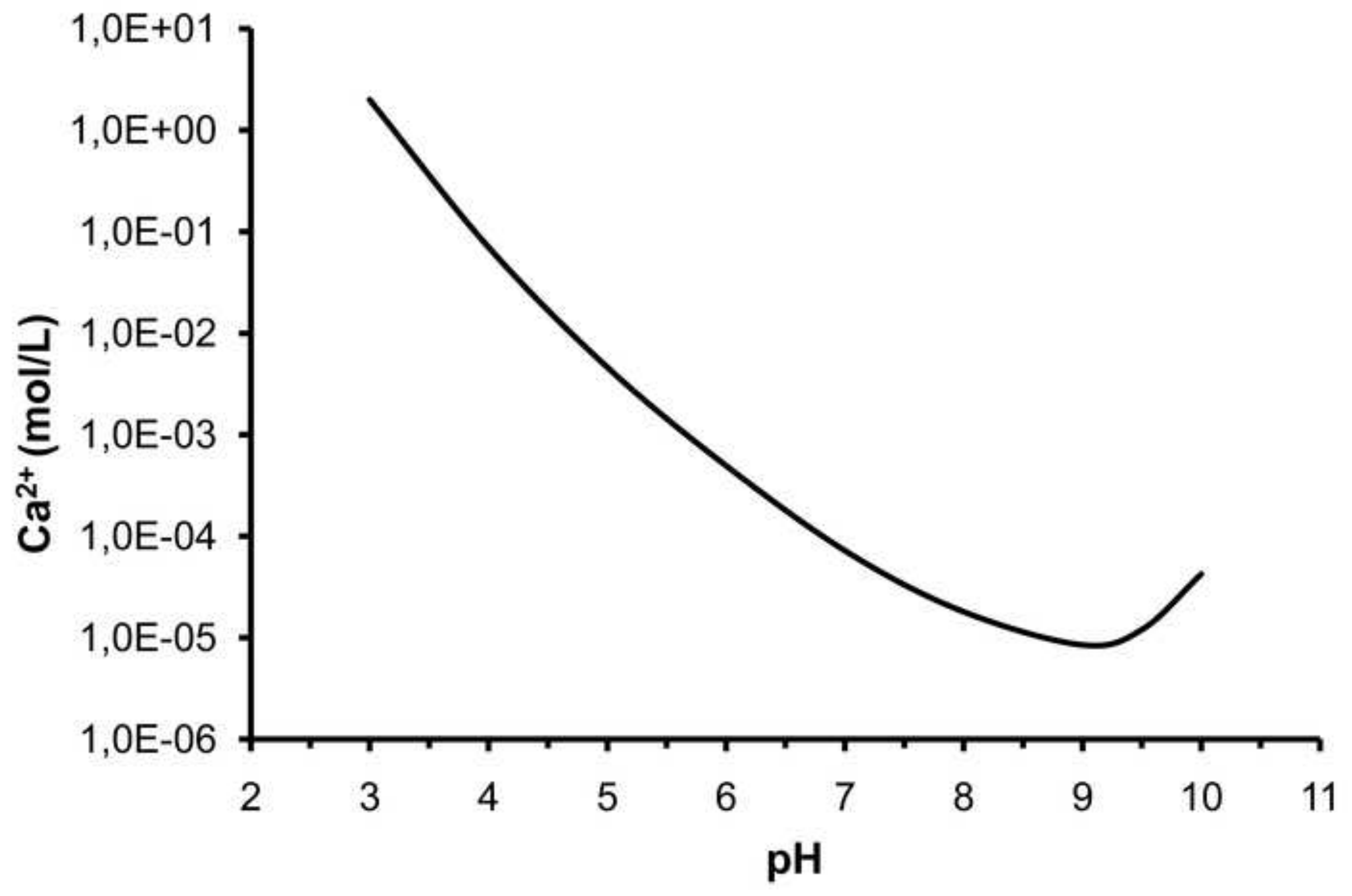




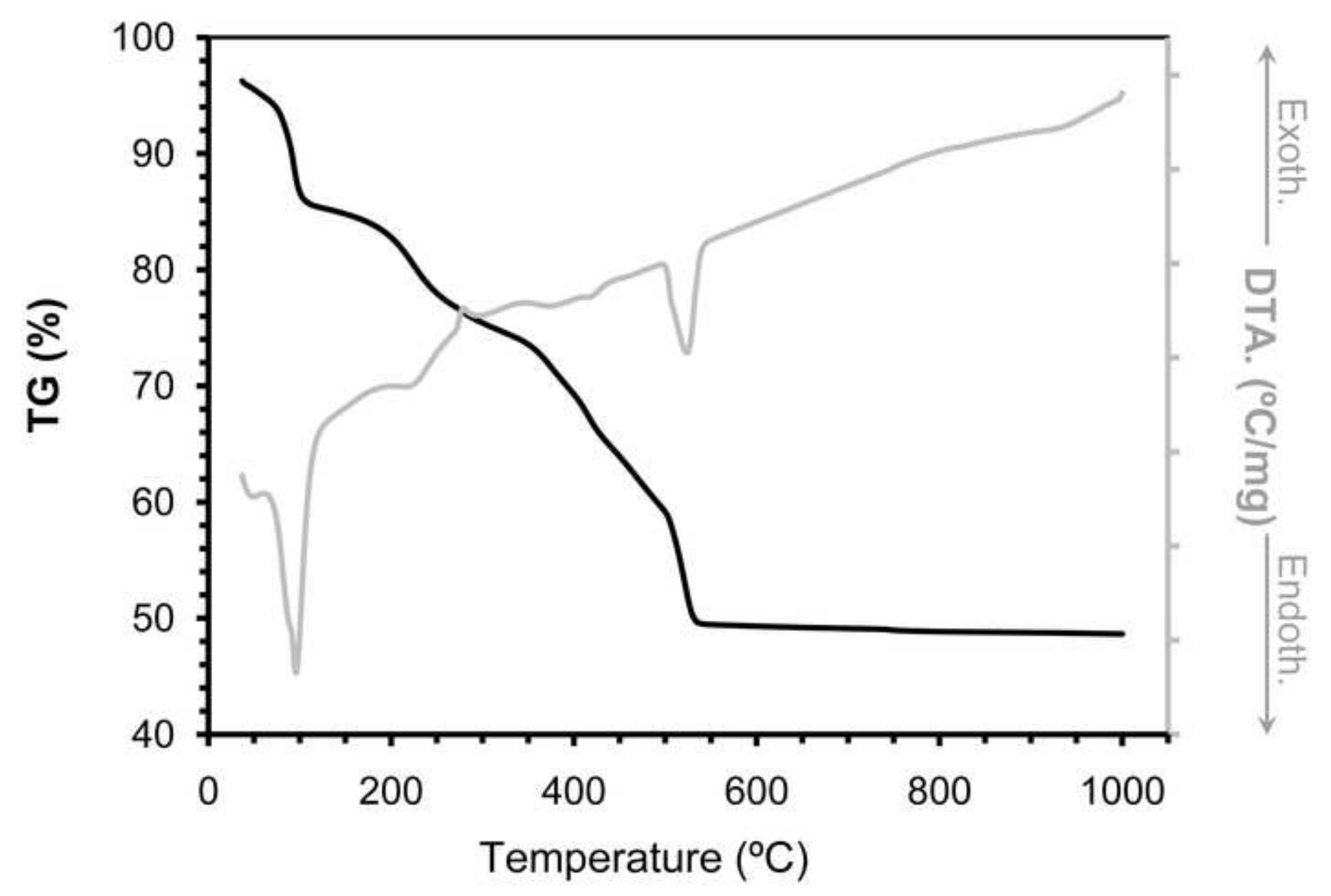




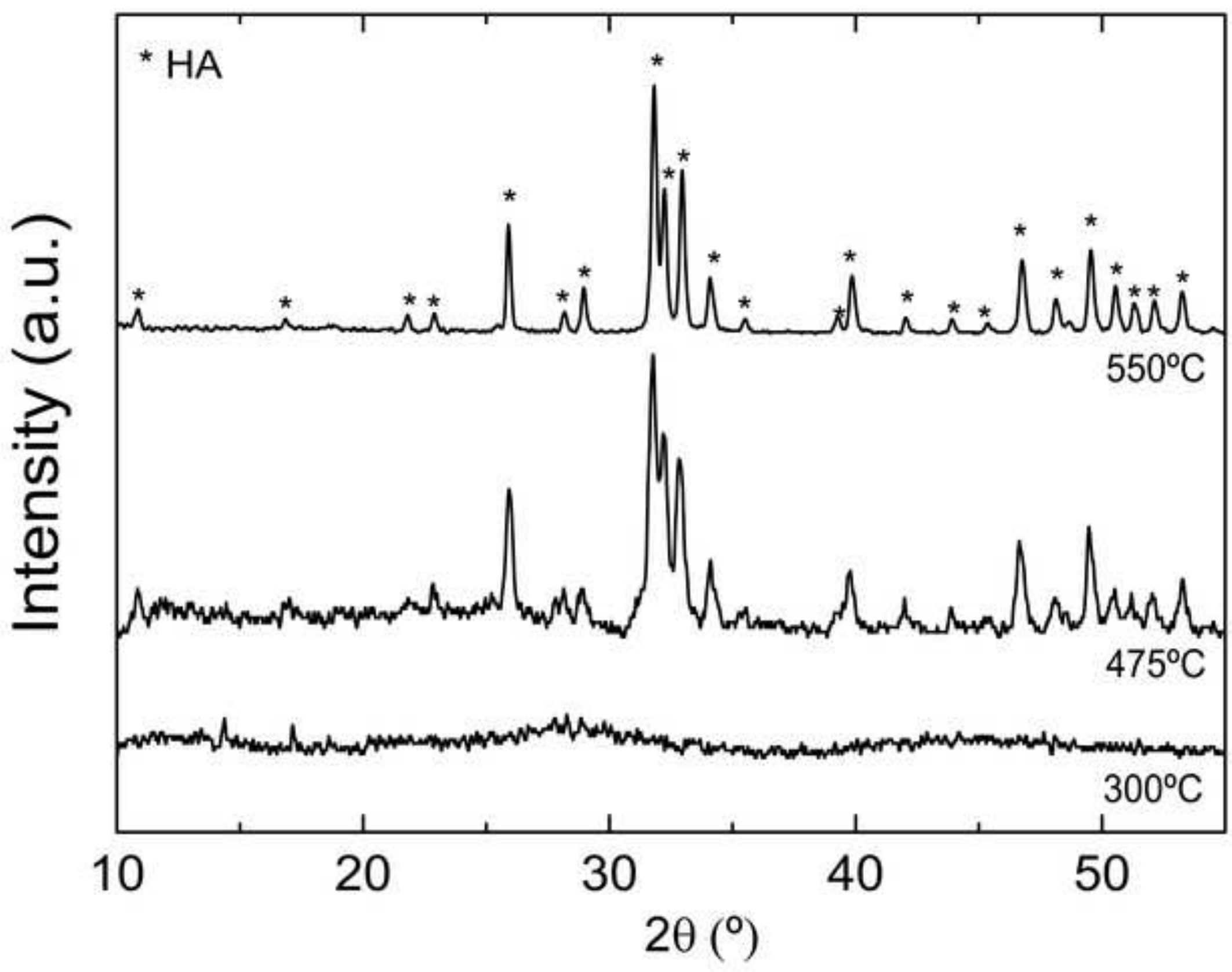




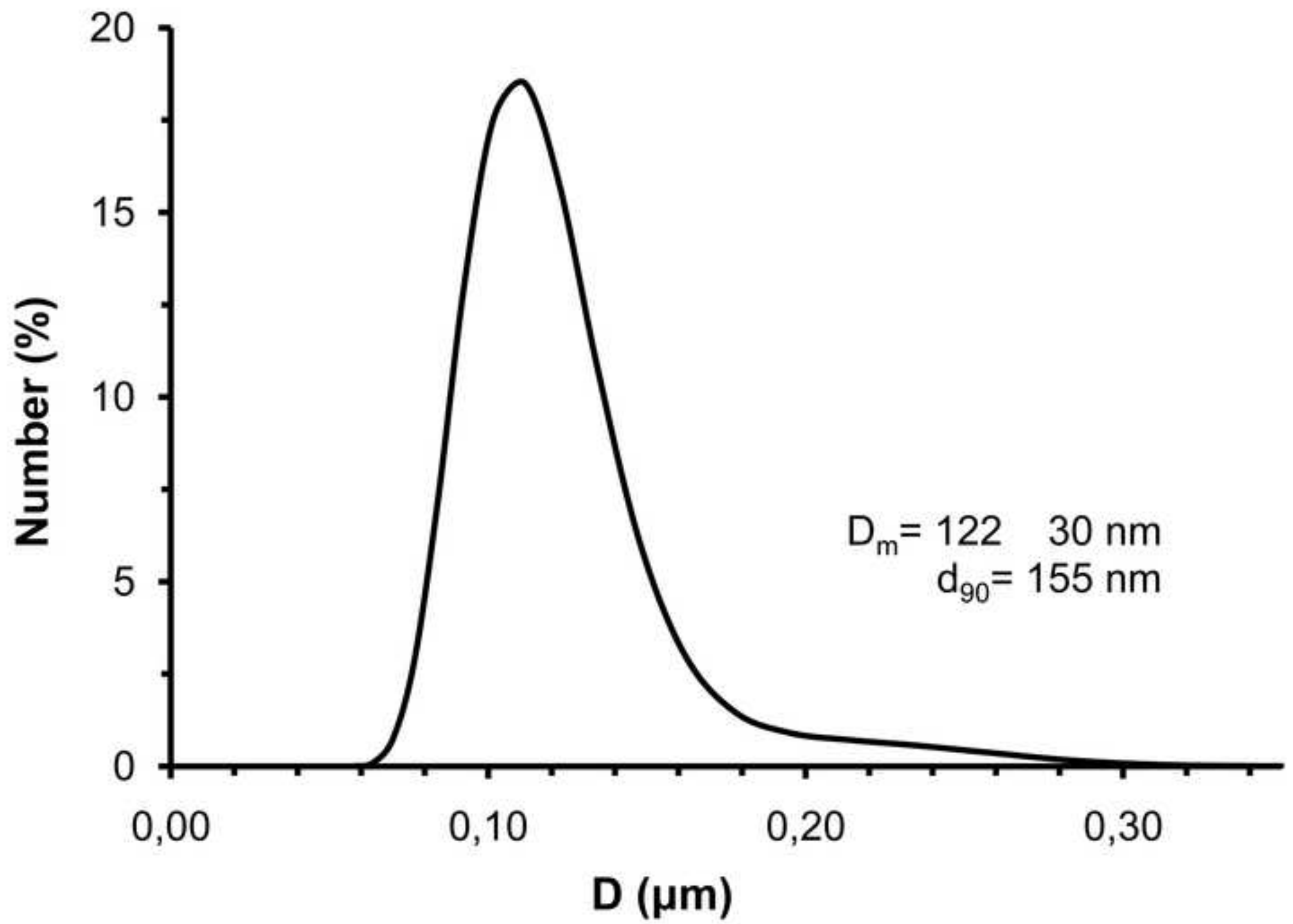




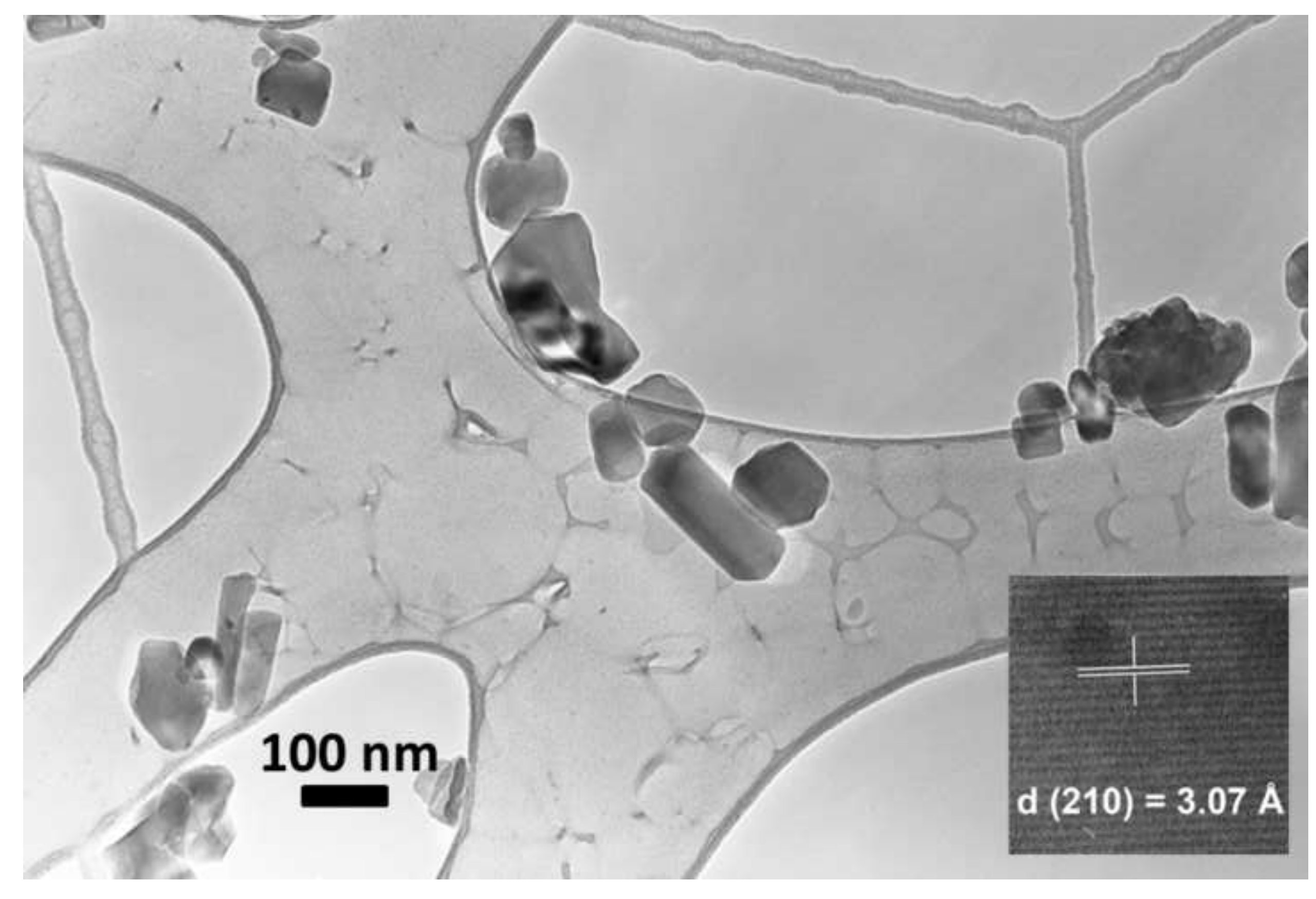

Figure 4B
Click here to download high resolution image 


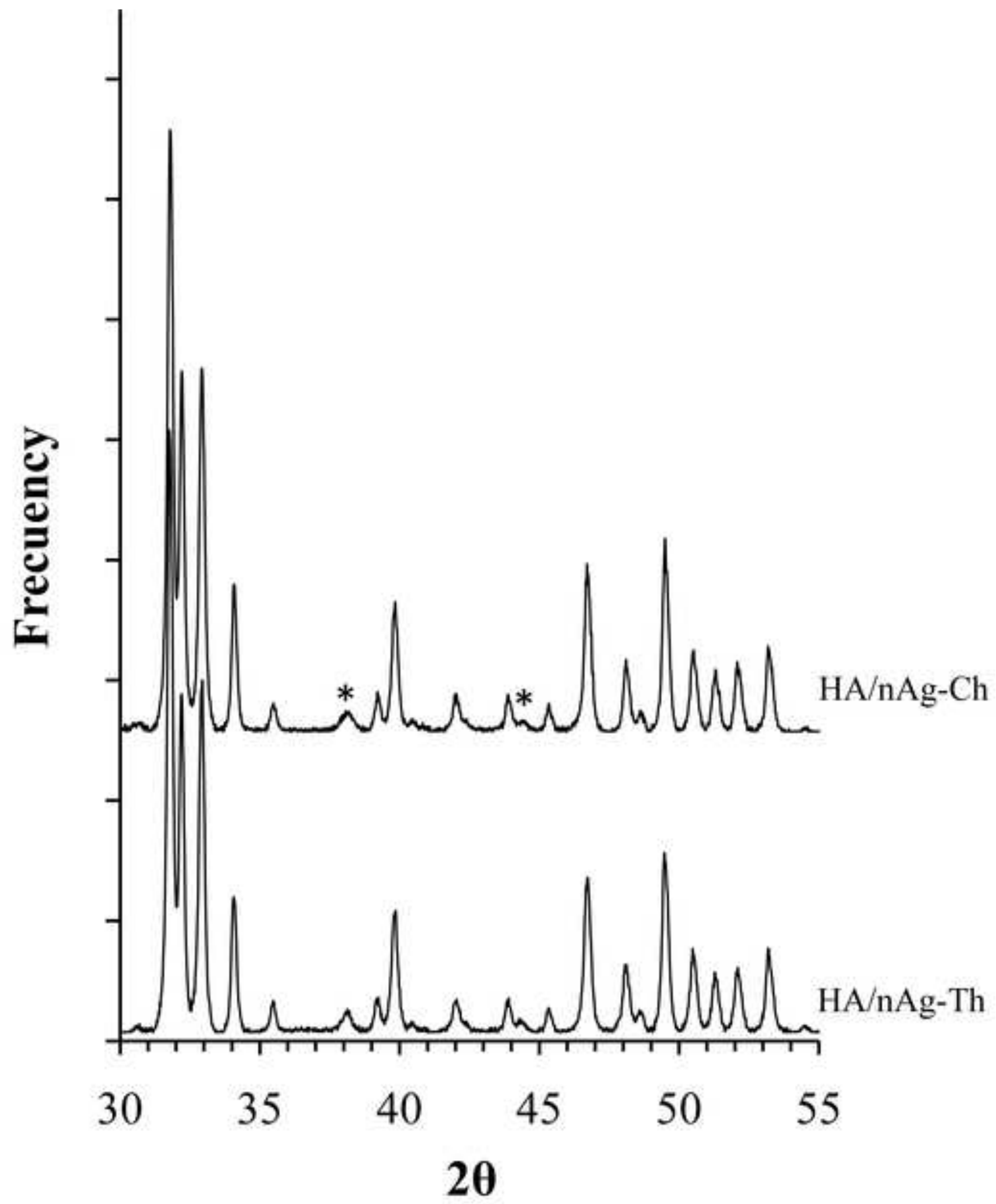




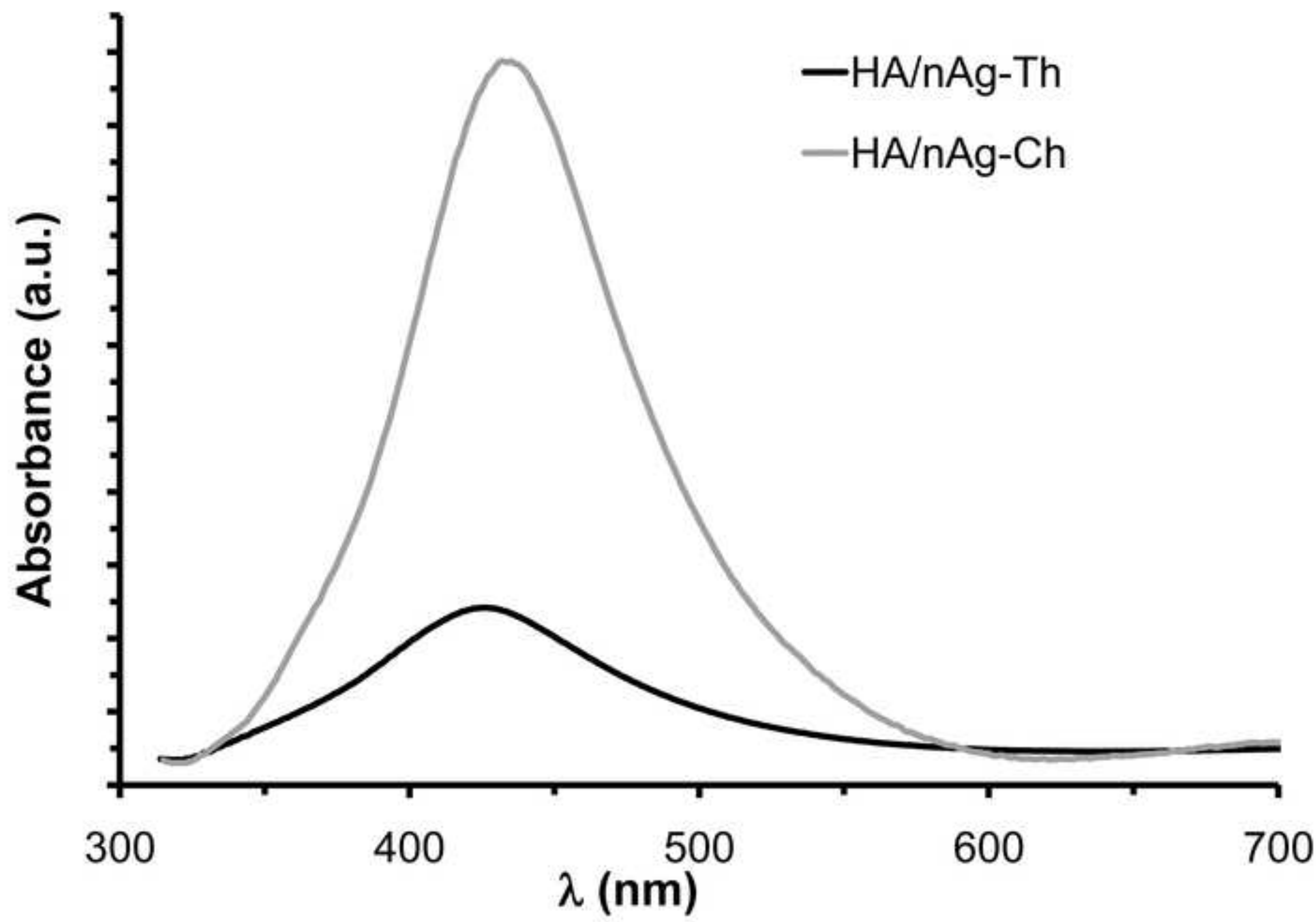




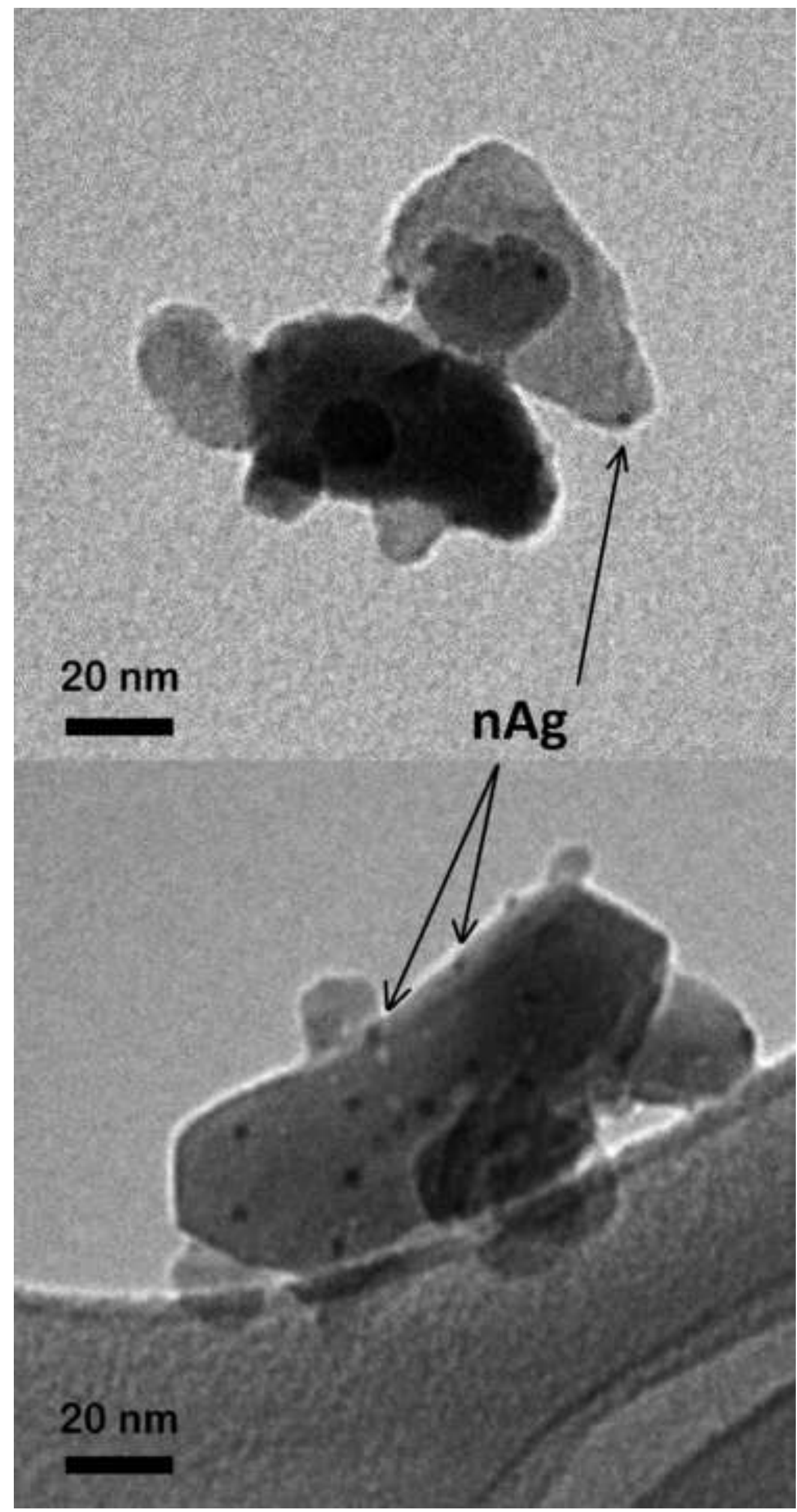




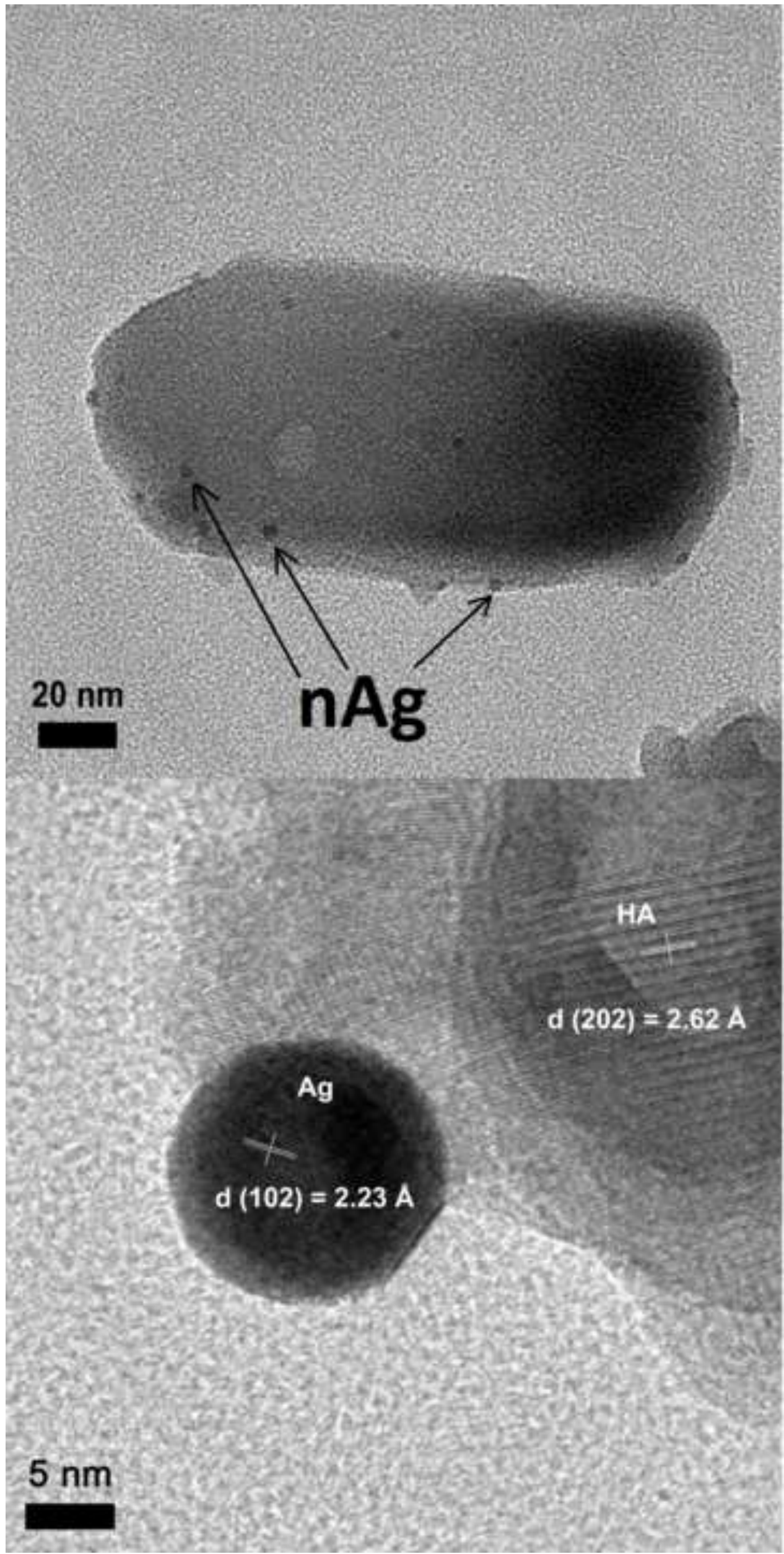




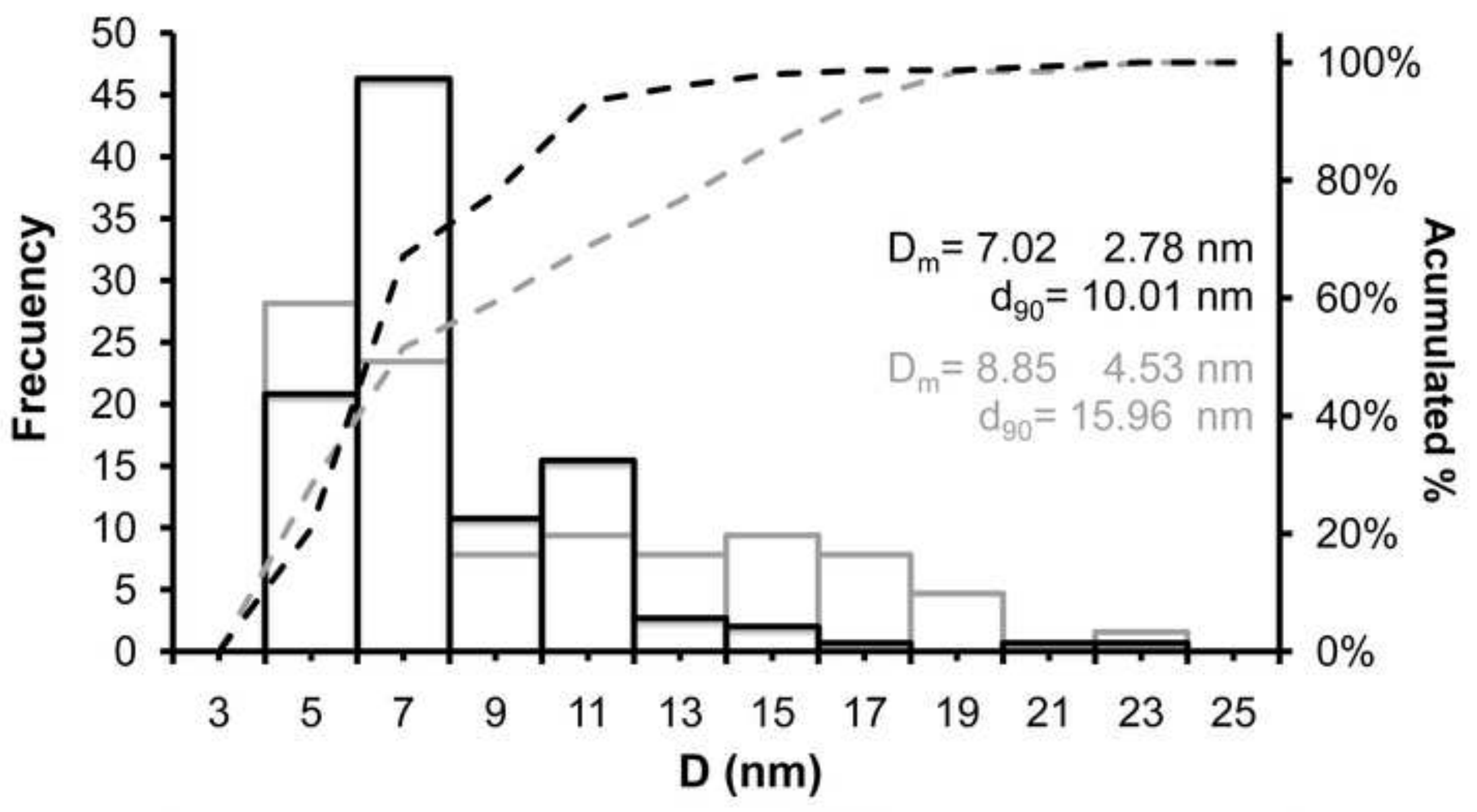

$\square$ Frecuency thermal reduc. - -Acumulated \% thermal reduc $\square$ Frecuency chemical reduc.

- -Acumulated \% chemical reduc 


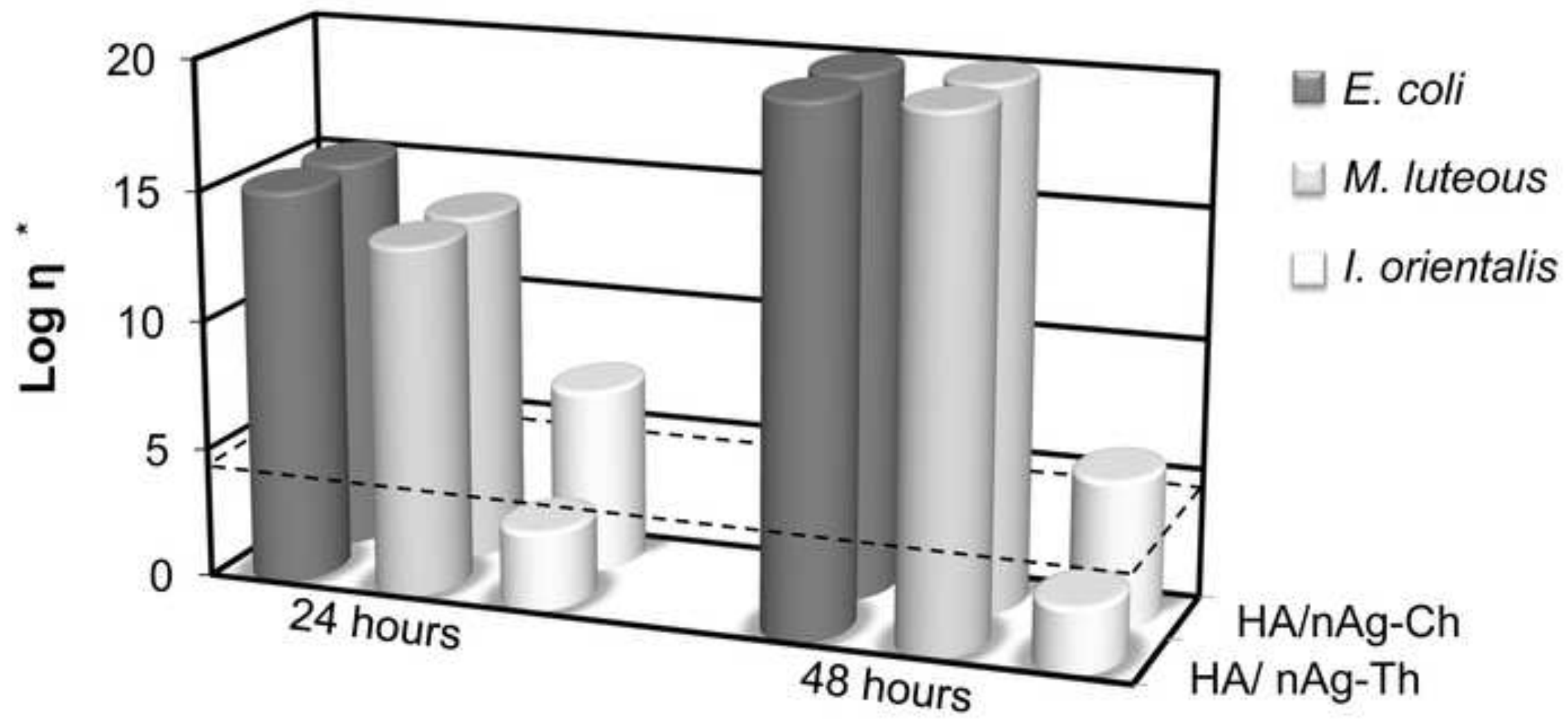

* $\log \eta=$ Log (control microorganisms) - Log (sample microorganisms)

- - - Commercial broad-spectrum antibacterial/antimicrobial 


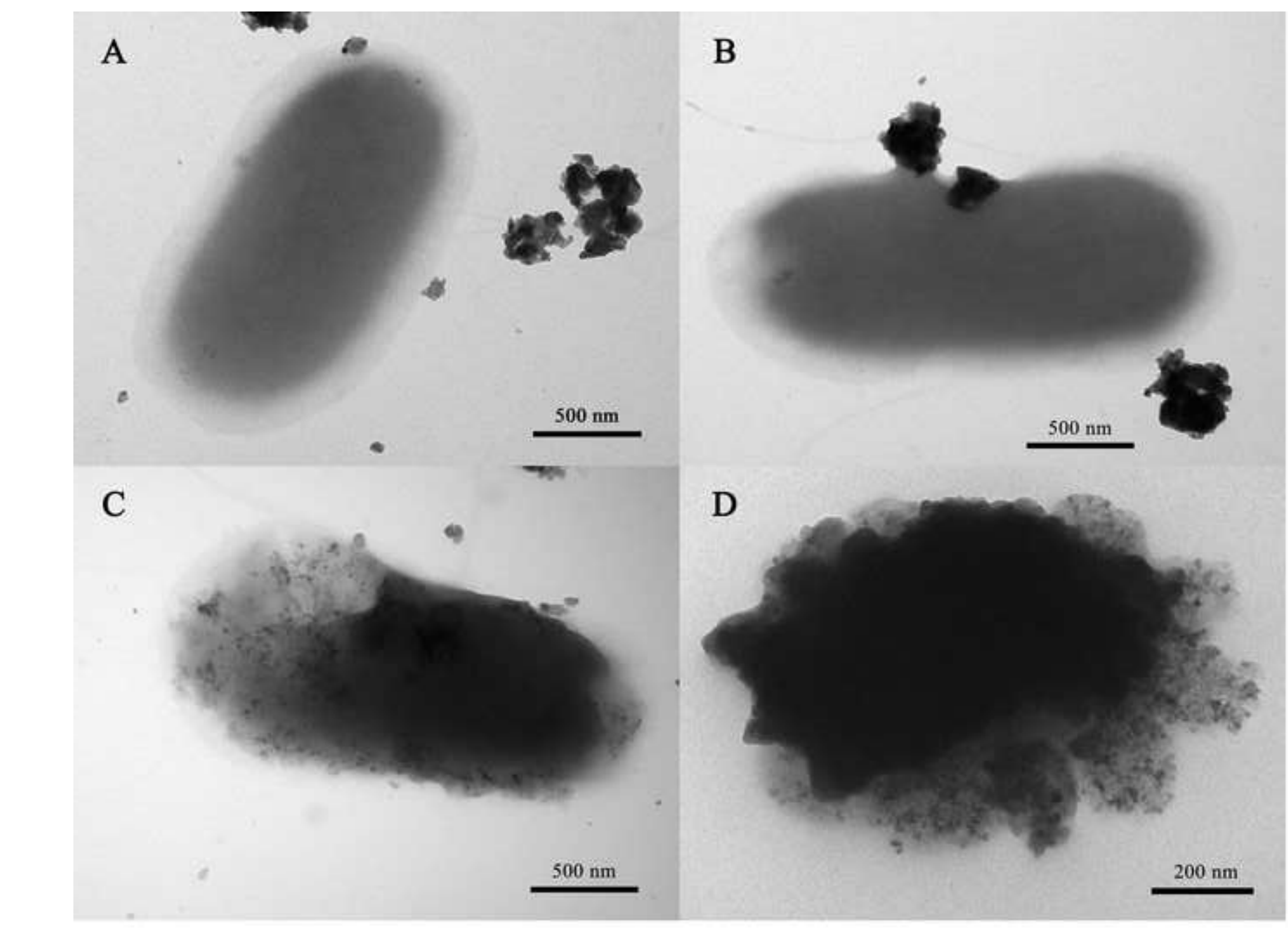

\section{Figure 9
Click here to download high resolution image \\ re to download high resolution image}




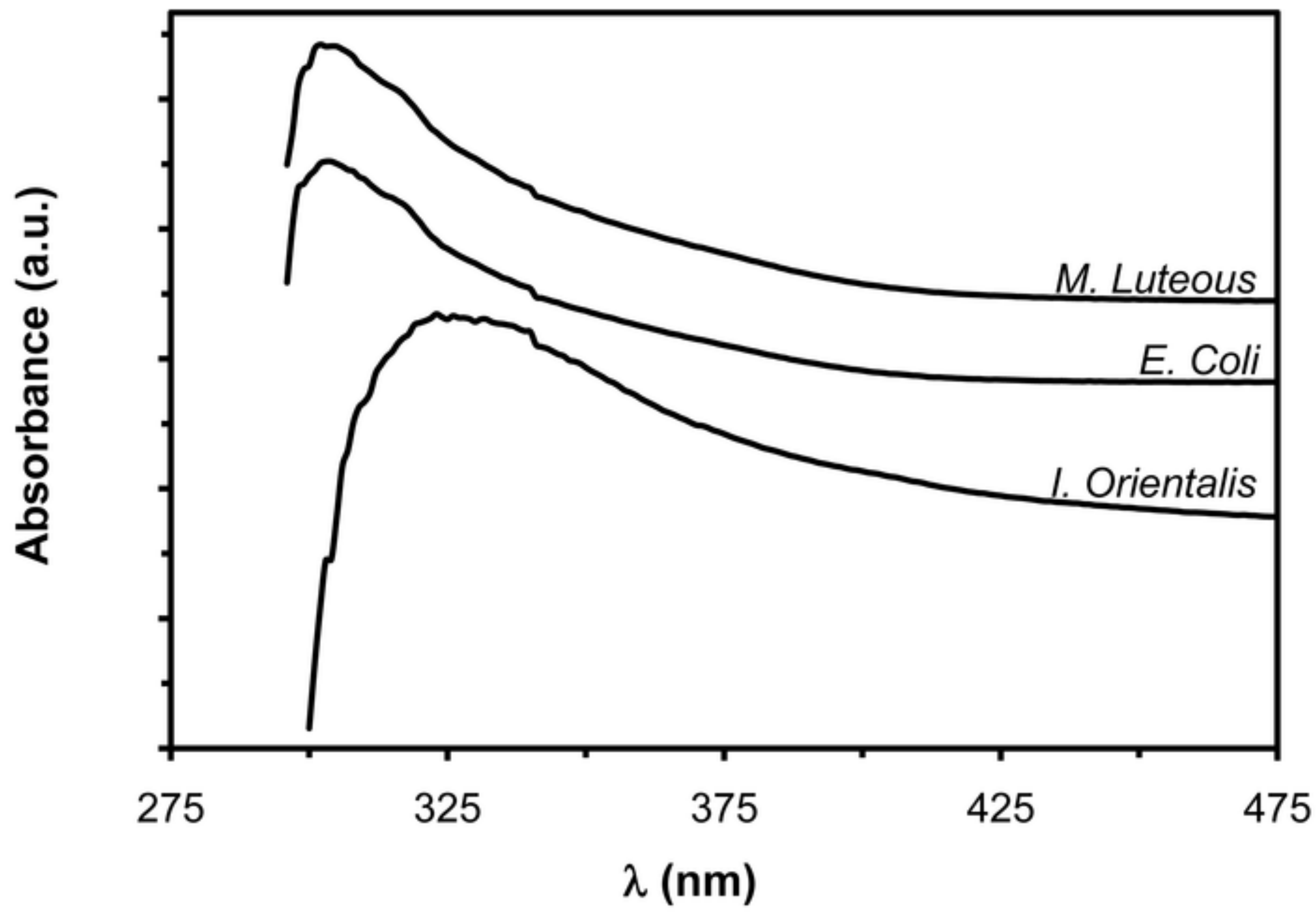


Table 1. Particle size distribution of silver nanoparticles obtained by different dry processes.

\begin{tabular}{cccc}
\hline Sample & Dry treatment & Size (nm) & D $_{\mathbf{9 0}}$ \\
\hline $\mathrm{HA} / \mathrm{nAg}-\mathrm{Ch}-60$ & $60^{\circ} \mathrm{C}$ & $9.7 \pm 3.8$ & 15.9 \\
\hline $\mathrm{HA} / \mathrm{nAg}-\mathrm{Ch}-150$ & $150^{\circ} \mathrm{C}$ & $9.9 \pm 2.2$ & 16.7 \\
\hline $\mathrm{HA} / \mathrm{nAg}-\mathrm{Ch}-250$ & $250^{\circ} \mathrm{C}$ & $8.9 \pm 3.1$ & 11.1 \\
\hline $\mathrm{HA} / \mathrm{nAg}-\mathrm{Ch}-\mathrm{L}$ & Lyophilization & $7.0 \pm 2.8$ & 10.1 \\
\hline
\end{tabular}


Table 2. Silver concentration measured in the lixiviated liquid after the biocide tests.

HA/nAg-Th

Ag concentration (ppm)
HA/nAg-Ch

pH $\overline{\text { Ag concentration (ppm) }}$ pH

\begin{tabular}{lcccc}
\hline E. Coli & 1.981 & 6.716 & 1.184 & 6.57 \\
\hline M. Luteous & 1.199 & 7.030 & 1.342 & 6.93 \\
\hline I. Orientalis & 0.008 & 6.733 & 1.614 & 6.64
\end{tabular}

(6.733

1.614

